in industrial production, and it was noted with regret that this fact is apparently not appreciated by the Government of Eire. No chemist has been appointed to either the Irish Industrial Development Council or the Council of Education, although the members of that Institute feel it should be obvious that many matters coming before these bodies for consideration deal with subjects in which the advice of a properly qualified and experienced chemist would be invaluable.

\section{Institute of Petroleum : Officers for 1950-51}

OFFICERS of the Institute of Petroleum for the year 1950-51 have been elected as follows. President : C. A. P. Southwell, managing director, Kuwait Oil Co., Ltd. Vice-Presidents : M. A. L. Banks, manager of operating branch, Refining Division, Anglo-Iranian Oil Co., Ltd. ; E. J. Dunstan, director, Manchester Oil Refinery, Ltd.; Prof. F. Morton, professor of chemical engineering, University of Birmingham ; J. S. Parker, refinery manager, Lobitos Oilfields, Ltd. ; H. C. Tett, general sales manager, Anglo-American Oil Co. Honorary Secretary : C. Chilvers, manager, Costs and Operations Department, Anglo-American Oil Co., Ltd. Honorary Treasurer : G. H. Coxon, Anglo-Iranian Oil Co., Ltd.

\section{Colonial Service: Recent Appointments}

THe following appointments in the Colonial Service have recently been announced: R. W. Kettlewell (senior agricultural officer, Nyasaland), deputy director of agriculture, Nyasaland ; C. J. MeGregor (senior agricultural officer, Tanganyika), regional assistant director, Tanganyika; B. G. Montserin (cocoa agronomist, Trinidad), chief scientific officer, Trinidad; A. V. W. Ping (assistant agricultural superintendent, British Guiana), agxicultural superintendent, British Guiana; G. M. Rodhan (deputy director of agriculture, Kenya), director of agri. culture, Nyasaland; N. V. Rounce (senior agricultural officer, Tanganyika), regional assistant director, Tanganyika; A. H. Savile (senior agricultural officer, Tanganyika), regional assistant director, Tanganyika ; H. P. Smart (senior agricultural officer, Tanganyika), regional assistant director, Tanganyika; A. F. Barker, lecturer in physics, Yaba Technical Institute, Nigeria; J. A. F. Russell, lecturer in mechanical engineering, Yaba Technical Institute, Nigeria; $\mathrm{K}$. Welding, assistant engineer, Public Works De. partment, Federation of Malaya; J. W. Henderson, assistant conservator of forests, Gold Coast; G. Jefford, chemist assayer, Nigeria; E. P. Wells, veterinary officer, Uganda; R. I. G. Attwell, biologist, Northern Rhodesia; R. J. B. Power, field zoologist, tsetse fly survey and control (Veterinary Department), Kenya ; C. H. Sharpston, statistician, East Africa High Commission.

\section{The Night Sky in June}

N.w moon occurs on June 15d. 15h. 53m., U.T., and full moon on June $29 \mathrm{~d}$. $19 \mathrm{~h}$. $58 \mathrm{~m}$. The following conjunctions with the moon take place: June 6d. 17h., Jupiter $2^{\circ}$ N.; June 12 d. 08h., Venus $6^{\circ}$ S.; June 13d. 17h., Mercury $8^{\circ}$ S.; June 2ld. 23h., Saturn $0.4^{\circ} \mathrm{N}$.; June 23d. Ilih., Mars $0.4^{\circ} \mathrm{N}$. Mercury is a morning star but is too close to the sun to be easily observed. Venus, a morning star, rises at $2 \mathrm{~h} .30 \mathrm{~m}$., $2 \mathrm{~h} .10 \mathrm{~m}$. and $1 \mathrm{~h} .55 \mathrm{~m}$., at the beginning, middle and end of the month, respectively, and can be seen for a short period before sunrise. Mars sets at $1 \mathrm{~h} .20 \mathrm{~m}$. and $23 \mathrm{~h} .40 \mathrm{~m}$. on June 1 and 30, respectively. On June 22 the planet has the same Right Ascension as $\eta$ Virginis and is a little more than $1^{\circ}$ south of the star in Declination. Jupiter rises at $0 \mathrm{~h} .50 \mathrm{~m}$. on June 1 and at $23 \mathrm{~h} .00 \mathrm{~m}$. on June 30 , and can be seen for a few hours before sunrise in Aquarius. The planet is stationary on June 27, after which its motion is retrograde. Saturn, in the constellation of Leo, sets at $1 \mathrm{~h} .05 \mathrm{~m} ., 0 \mathrm{~h} .10 \mathrm{~m}$. and $23 \mathrm{~h} .15 \mathrm{~m}$. on June 1,15 and 30 , respectively. No occultations of stars brighter than mag. 6 occur in June. Summer solstice is on June 22d. 00h.

"Indenone-Carboxylic Acids and allo-Dunnione"

THe communication under this title by $R$. G. Cooke and T. C. Somers, published in Nature of February 25, p. 314, contains two printing errors. The structural formula (II) should read as follows :

$$
\int_{\mathrm{CO} \cdot \mathrm{CH}_{2} \cdot \mathrm{Bu \gamma}}^{\mathrm{CO} \cdot \mathrm{COOH}}
$$

Also, in line 2 of the last paragraph the name of the compound produced was 2-iso-propyl-indanone-3-carboxylic acid (m.p. 103-104 ${ }^{\circ}$ ), not . . . indenone . . . as printed; the 'anone' ending applies only in this one instance.

\section{Announcements}

The Osler Memorial Medal for 1950 of the University of Oxford has been awarded to Sir Ernest Kennaway, emeritus professor of experimental pathology in the University of London.

Mr. Denis Richards, author of the earlier half of the R.A.F. "short" Official History soon to be published, is to succeed the late Mrs. Eva Hubback as principal of Morley College for Working Men and Women, Westminster Bridge Road, London.

THE following appointments in the University of Leeds have recently been announced: Dr. R. A. Willis, director of the Pathology Department, Royal Cancer Hospital, London, to the chair of pathology ; and Dr. F. S. Dainton, H. O. Jones lecturer in the Department of Physical Chemistry, Cambridge, to the chair of inorganic and physical chemistry.

Prof. W. Hamilton WhYte, professor of economies in the University of Bristol, has been appointed director of the Institute of Social and Economic Research at University College, Ibadan, Nigeria. $\mathrm{He}_{\Theta}$ will take up his duties in September next. The Institute, like that at Makerere College, East Africa, under the directorship of Dr. Audrey Richards, and the Institute at the University College of the West Indies, under Dr. H. D. Huggins, will initiate and co-ordinate research in the social sciences with special reference to local conditions.

Honorary associateships of the Birmingham Central Technical College have been conferred on the following: Mr. Frank G. Woollard, director of the Midland Motor Cylinder Co., Ltd.; Mr. J. W. Donovan, joint managing director of the Donovan Electrical Co., Ltd., and chairman of the South Midlands Branch of the Institution of Electrical Engineers; Mr. T. H. Gant, chief engineer of British Industrial Plastics, Ltd. ; and Dr. M. Cook, research director of the Metals Division of Imperial Chemical Industries, Ltd., and president of the Institution of Metallurgy. 